\title{
The Use of SQ3R Method in Improving Quality and Result of Social Sciences Learning in XI Grade SMAN 3 Kendari Southeast Sulawesi Indonesia
}

\author{
Jamiludin \\ Halu Oleo University, Indonesia \\ jamiludin1964@yahoo.com \\ Darnawati \\ Halu Oleo University, Indonesia \\ darnawati@gmail.com
}

\author{
Jumatin \\ Halu Oleo University, Indonesia \\ jumatin@gmail.com \\ Waode Ade Sarasmita Uke \\ Halu Oleo University, Indonesia \\ waode.ade@gmail.com
}

\begin{abstract}
Most of teachers still use traditional way to teach. Especially, Social science learning in the classroom teachers still use lecture and question and answer methods. However, lecture and question and answer methods have not been able to fully improve the activity and quality of student learning. Good student learning quality can reflect good student learning outcomes. Smart students tend to dominate learning but for the less intelligent students are silent. One way that can be taken to overcome these learning problems is to make improvements to the learning pattern that is with the application of learning methods SQ3R.This study aims to (1) describe the application of the SQ3R method in Social science learning in high school students at XI grade, (2) to improve the quality of social science learning in high school students at XI grade, and (3) improve social science learning outcomes in high school students at XI grade. This study use research and development design. The participants are the high school students at XI grade. The result of this study were conducted by two steps. The first step conducted literature and field studies, the suitability of school learning curriculum, and analysis of student learning competency achievement. The next step was to do the implementation of SQ3R model. The resulting model can improve the quality of learning and learning outcomes of social science learning in high school students at XI grade.
\end{abstract}

Keywords: SQ3R method, quality and result of learning, social science

\section{INTRODUCTION}

The development and changes that occur in the world of education is inseparable from the influence of global change, as a result of the development of science and technology. This continuous change requires the need for improvement in the national education system including techniques or teaching methods in the classroom. Teachers' learning methods in general still use a much easier approach to teachers (teacher centered) is to identify learning by memorizing the subject matter that will be tested, not on giving understanding to students how to understand the value or concept.

Students almost never see any connection between subject matter and its benefits. The existing material that has been memorized will soon be forgotten when the exam process ends. This shows that learning is not able to empower learners as individuals who have various potential to develop. Such conditions, with the presentation of the material more dominated teachers and less opportunities for students in developing the potential that exists in him, become one of the indicators of learning English IPS less quality because learning does not show fun nuances and neglected student activities. Many students who are smart and strong for students who are less smart just stand still. That is, it is reliable in the low student learning outcomes especially in IPS lessons.

The quality of education in Indonesia especially in Social Sciences subjects needs special attention, since it is nothing but subjects or courses that complement each other with social sciences and humanities.

The lack of an active role of learners in the learning process becomes one of the benchmarks if less quality learning. Therefore, the lesson is applied not on how the ability to think the same as before. But just accept anything that is explained by the teacher oriented to the completeness of the material solely, so the learning achievement was only seen in the learning outcomes achieved by students after learning.

Learning outcomes as an indicator of the success of the learning process, is one of the problems that never runs out in the world of education. Some of the factors that are developing learning outcomes, among others, teaching learning, student learning environment, learning media, and learning models applied by teachers in the classroom. When it occurs with the teaching process, then the important factor that is directly related is the application of a model of learning in the classroom, which results directly on improving the activity and quality and student learning outcomes.

The lack of quality IPS lessons that impact the low learning outcomes that students wake up, one of the causes is the subject matter IPS is too dense and widespread and aggravated again by the low interest in reading for learners. Therefore, one of the solutions that can be pursued is by the method of improvement or proper reading techniques and effective. The reading technique in question is the way Robinson reads the Survey-Question-Read-Recite-Review or abbreviated SQ3R (Kiranawati, 2008). In SQ3R technique contained vocabulary mastery, organizing reading materials, linking facts to one another.

Based on the basic methods of thinking above, then the method of learning SQ3R in addition to maximize student activity jug adaptation on improving the quality and student learning outcomes. The problems in this research are formulated as follows: (1) how is the description of SQ3R method in social science learning?; (2) can the SQ3R method improve 
the quality and learning outcomes of student learning in social science learning?

\section{METHODS}

This research uses a research and development approach with classroom action research. $\mathrm{R} \& \mathrm{D}$ is used for the development of learning models while CAR is used to know or test the effectiveness of SQ3R model implementation. In general, the stage or procedure of development in this research consists of six (6) steps, namely:

1. Introduction or needs analysis. Activities at this stage include literature studies and field studies. The literature study was conducted to gather information regarding reference sources, curriculum and course descriptions, classroom observations and research framework design. While the field study is done by looking directly at the learning process, the characteristics of the students, the way students learn and documents the results of student studies.

2. Development of instructional design. In this second stage, the development of instructional design begins with the preparation of syllabus, RPP, Development of Materials / Materials, and designing evaluation tools / instruments.

3. Formative evaluation or validation by experts regarding materials that have been designed before by the developer, followed by small group evaluation (small group evaluation).

4. The fourth step is the implementation or implementation of the SQ3R model in learning. The application or implementation of the SQ3R model (Survey, Question, Read, Recite and Review) follows the implementation stages in the classroom action research. Measures for implementing the intended actions include: (a) preliminary activities, convey the purpose of learning, motivate students, and apersepsi; and (b) core activities, organizing students into groups, lecturers guiding groups to work on applying SQ3R learning models, each group presenting their work and group others responded, and the lecturer gave feedback and concluded the work of the group and the discussion; and (c) closing activity; lecturers with students conclude the results of the discussion and give the task / evaluation.

5. The fifth step is summative evaluation. This evaluation serves to determine the effectiveness of SQ3R model in improving the quality of learning in the form of increased achievement of student learning outcomes.

6. The sixth step is dissemination. This stage is the stages of publication either through seminars, print media / online or in national or international scientific journals.

The subjects of this study are students of SMA Negeri 3 Kendari IPS class XI. The data collection in this research is done in two (2) stages. Stage 1 (year 1), focused on development aspect. The development of the SQ3R model in question is done through literature study, field study, instructional design development, expert validation and small group evaluation on the design of learning materials created by the developer / researcher. While in phase 2 (year 2), focused on the implementation / implementation of SQ3R model in classroom learning, evaluation of effectiveness test (to know the quality and learning outcomes) and dissemination. The data in question to be analyzed is the students' learning completeness data after the application of SQ3R learning method. The data are analyzed descriptively quantitative. The analysis is used to determine the level of quality and learning hasl achieved by students. Prior to the quantitative descriptive test, first test the requirements analysis, the normality test and homogeneity test.

\section{Result}

\section{RESULT AND DISCUSSION}

This research was conducted in two stages. First, research is conducted by: (1) needs analysis ie literature study and field study; (2) design of learning materials; and (3) expert validation and small group evaluation. While in the second stage, the research was conducted by: (1) implementation of SQ3R model; (2) final evaluation / effectiveness test; and (3) dissemination / publication.

\section{Description of Needs Analysis}

The results of needs analysis obtained data / information, among others: (1) learners have difficulties in understanding learning materials IPS in particular, because the material is quite widespread and so complex, (2) learning practices that are implemented for all subjects especially in the IPS Department is generally the same with the methods of lectures and discussions, and (3) the low interest in reading students who have an impact on the lack of mastery of taught material. Therefore, learning IPS is needed a proper and effective reading method of learning method SQ3R.

In addition, the collection of information in needs analysis is also done through literature studies and field studies. Information or data collected from these study activities, among others, is to learn about the characteristics of the course, the applicable curriculum structure, learning tools syllabus and RPP, and other reference books.

\section{Content Design (Devices and Materials)}

The resulting device designs include: preparation of syllabus and RPP. The development of this syllabus consists of eight steps: (1) determining the standard of competence; (2) determining basic competence; (3) formulating indicators and learning objectives; (4) determining learning materials; (5) developing learning strategies; (6) developing learning scenarios; (7) developing assessment instruments; and (8) designing evaluation tools. While the design of learning materials is done by collecting some literature / reference. The material produced is a book-shaped instructional material as a guide in learning social studies.

\section{Description Expert Validation}

To produce the quality of material design, then validation is done by experts (ekspertjudgment) who have competence in the field. Forms assessment by using a questionnaire likert scale with categories not good, less, enough, good and very good. Expert validation results on the aspect of the device, shown in Table 1. While the results of expert validation on the material aspects, shown Table 2 . 
Table 1

Expert Validation Results on the Aspect of The Device

\begin{tabular}{|c|c|c|c|}
\hline No & Indicator & Score & Category \\
\hline 1. & Clarity of success indicators & 4 & Good \\
\hline 2. & $\begin{array}{l}\text { Consistency between competency standards, basic competencies, } \\
\text { indicators, materials, learning strategies and evaluation tools }\end{array}$ & 4 & Good \\
\hline 3. & Giving motivation & 4 & Good \\
\hline 4. & Systematic components of syllabus and RPP preparation & 4 & Good \\
\hline 5. & Clarity of material description & 5 & Very good \\
\hline 6. & Clarity of study instructions & 4 & Good \\
\hline 7. & Variations on how to present the material & 4 & Good \\
\hline 8. & Examples & 4 & Good \\
\hline 9. & Giving exercises for conceptual understanding & 4 & Good \\
\hline 10. & Giving opportunities for self-study & 4 & Good \\
\hline 11. & Giving feedback & 5 & Very good \\
\hline 12. & Clarity of instructions on the test & 3 & Enough \\
\hline 13. & The quality of the test and its assessment & 5 & Very good \\
\hline 14. & Material balance with test questions & 4 & Good \\
\hline & $\begin{array}{c}\text { Total score } \\
\text { Average } \\
\text { Score } \\
\end{array}$ & $\begin{array}{c}58 \\
4.14\end{array}$ & \\
\hline
\end{tabular}

Table 2

The Results of Expert Validation on the Material Aspects

\begin{tabular}{clcc}
\hline No & \multicolumn{1}{c}{ Indicator } & Score & Category \\
\hline 1. & The truth of the concept & 3 & Enough \\
2. & Material actuality & 5 & Very good \\
3. & Urgency of each material & 3 & Enough \\
Good & Very good \\
4. & Material systematics & 4 & Good \\
5. & Material compatibility with student characteristics & 5 & Very good \\
6. & Adequacy of material to achieve goals & 5 & Good \\
7. & The breadth and depth of matter & 4 & Good \\
8. & Accuracy of examples to clarify & 3 & Good \\
9. & The suitability of the image to clarify the contents & 4 & Good \\
10. & Clarity of language use & 4 & Good \\
11. & Clarity of the formulation of the problem & 4 & $\mathbf{4 8}$ \\
12. & The level of difficulty of the problem in accordance with the competence & $\mathbf{4}$ & Good \\
\hline
\end{tabular}

\section{Description of Learning Quality}

Data on the quality of learning through the SQ3R method obtained through the development of instrument indicators consisting of seven aspects of which are: (1) the ability of learning management; (2) the ability to communicate effectively; (3) the ability of material mastery; (4) positive attitude toward students; (5) approach in learning; (6) awarding exams and assessments. The category of learning quality applied using Likert scale with five; and (7) option answers, ie category is very good, good, enough, not good, and very bad.

The number of items used as many as 30 items spread in each indicator. Data of learning quality analysis result, presented in Table 3. Based on the results of the analysis above, it shows that the quality of learning applied in SQ3R method is in good category. Thus, the SQ3R method can improve the quality of student learning in the classroom.

\section{Discussion}

This research was conducted with several steps, including the development of SQ3R method, material validation by expert and effectiveness test to know the quality of learning and improvement of learning outcomes in the subjects of social studies in SMA Negeri 3 Kendari students. The application of the SQ3R learning method is intended to present to students the way or techniques of effective reading.
One of the objectives is to describe the stages of the implementation of the SQ3R learning method. In addition, conducted to determine the quality of learning and student achievement outcomes in social science subjects.

Implementation of this learning method is tailored to the existing school schedule and applicable curriculum. But before, beginning with the preparation stage of the discussion of the implementation plan of learning, facilities and infrastructure, learning media characteristics and the initial ability of each student.

The findings in this scientific research found that the application of SQ3R learning methods to high school students in social science subjects showed improvement in quality and learning outcomes. Improving the quality of learning is shown by the enthusiasm of students in following the lesson and the decreasing of students' saturation because it presents learning that challenges the students. Improving the quality of learning affects the achievement of student learning outcomes.

Helping students to find and select information, teachers should establish, introduce and develop skills necessary to solve classroom learning problems. According to Brophy and Good (1995) to absorb the essence of reading effectively in learning can use SQ3R model. the workings of this model are: survey, before beginning to read first do a survey to get the picture contained in the book read. 
Table 3

Data of Learning Quality Analysis Result

\begin{tabular}{|c|c|c|c|}
\hline No. & Indicator & Average & Category \\
\hline A. & Learning Management Capabilities & & \\
\hline 1. & Class management. & 3 & Enough \\
\hline 2. & Timeliness of material presentation. & 4 & Good \\
\hline 3. & Conformity of material with learning objectives. & 4 & Good \\
\hline 4. & Giving motivation to learn. & 4 & Good \\
\hline B. & Ability to Communicate Effectively & & \\
\hline 5. & Skills explained. & 4 & Good \\
\hline 6. & Questioning skill. & 4 & Good \\
\hline 7. & Giving strength. & 4 & Good \\
\hline 8. & Interaction with learners. & 4 & Good \\
\hline 9. & Media usage. & 4 & Good \\
\hline 10. & Attention to student responses. & 5 & Very good \\
\hline 11. & Giving feedback with understandable language. & 5 & Good \\
\hline C. & Content Mastery Ability & & \\
\hline 12. & Clarity of formulation of learning objectives. & 4 & good \\
\hline 13. & Depth of material with student knowledge. & 4 & Good \\
\hline 14. & Contextual material & 4 & Good \\
\hline 15. & Giving material conclusions & 4 & Good \\
\hline 16. & Relevance of examples by the presentation of the material. & 4 & Good \\
\hline D. & Positive Attitudes to Students & & \\
\hline 17. & Respect the opinions of learners. & 3 & Enough \\
\hline 18. & The willingness of teachers helps students' difficulties. & 3 & Not good \\
\hline 19. & Encourage students to ask / express opinions. & 4 & Good \\
\hline 20. & Concern for student learning. & 2 & Not good \\
\hline 21. & Corrective feedback on student assignments. & 4 & Good \\
\hline E. & Approach in Learning & & \\
\hline 22. & Use of learning methods / models. & 4 & Good \\
\hline 23. & Group division for task completion. & 4 & Good \\
\hline 24. & Involvement of student activities in learning. & 4 & Good \\
\hline 25. & Giving time for self-study / grouping. & 5 & Very good \\
\hline F. & Granting Exam and Assessment & & \\
\hline 26. & Conformity with the material that has been studied. & 4 & Good \\
\hline 27. & Clarity of graduation criteria. & 4 & Good \\
\hline 28. & Clarity of assessment component. & 4 & Good \\
\hline 29. & The validity of the assessment with the ability of learners. & 3 & Enough \\
\hline 30. & Objectivity and clarity of assessment procedures. & 4 & good \\
\hline & Total Score & 117 & \\
\hline & Average & 3.9 & \\
\hline & Category of learning outcomes & \multicolumn{2}{|c|}{ Good } \\
\hline
\end{tabular}

Check out the chapter to be read in its entirety, what are the titles and subtitles. Question, ask questions that can guide us in reading activities. What issues will be discussed in the chapter and its subheadings, so as to discover / enter the essence of the chapter's idea. Read, read the contents of each section and find answers to questions that already exist in the second step.

Recite, writes key phrases that summarize all intents of the read section in their own words. Thus, the reader has captured the idea or essence of reading. Review, review the contents of the text; whether what we say in our own words is in accordance with the actual content or not. Next Robinson in his Effective Study introduces the SQ3R reading model in the following way:

1. Survey (review) is a reading step to get an overall picture of what is contained in the material being read. This is done by examining the titles and subtitles, drawings or illustrations, and the last summary in parts of the book or text in carrying out this survey is actually the students using skimming and scanning techniques.

2. Question (ask) is a step that requires students to solve a problem about the material or text after finding the material or text related to the needs of the task. These questions indicate the reader's desire to know about the message he wants to get from the material, and will try to find answers to the questions that are his job.

3. Read (read) is to read the material or text actively and try to get all the answers to questions that have been there before. When reading, students will gain additional knowledge based on the development of understanding and desire of what is read (analytical reading).

4. Recite (recall) is that after reading, the students recall what they have read and examine all that has been obtained. Knowledge that has been obtained and in accordance with the context of the task, students can answer questions.

5. Review (read / review) is the last step. Students read the sections of a book or text carefully to ascertain the answers to the questions made in step three and fourth (Kiranawati, 2008; Tarigan, 1994).

Helping students to find and select information, teachers should establish, introduce and develop skills necessary to solve classroom learning problems. According to Brophy and Good (1995) to absorb the essence of reading effectively in learning can use SQ3R model. the workings of this model are: survey, before beginning to read first do a survey to get the picture contained in the book read. Check out the 
chapter to be read in its entirety, what are the titles and subtitles. Question, ask questions that can guide us in reading activities. What issues will be discussed in the chapter and its sub-headings, so as to discover / enter the essence of the chapter's idea. Read, read the contents of each section and find answers to questions that already exist in the second step. Recite, writes key phrases that summarize all intents of the read section in their own words. Thus, the reader has captured the idea or essence of reading. Review, review the contents of the text; whether what we say in our own words is in accordance with the actual content or not.

The term quality contains many insights. Among them are conformity with certain standards, conformity with certain needs, correspondence with certain characteristics and conditions, alignment with the demands of the times, availability when needed, reliability in various conditions, the accuracy of material presentation, and high attractiveness and so on (Miarso, 2004). Sallis (2006) states that quality is a philosophical and methodological that helps institutions to plan change and set the agenda in the face of excessive external pressures.

The quality of education is generally associated with the level of effectiveness and efficiency of the classroom. Edwards (2011) notes that Quality Learning is an approach to improving learning and the quality of school life. It provides simple tools and methods to make classrooms and schools more efficient and effective. It means that the quality of learning is an approach to improving the learning and quality of school life. By providing simple tools, methods and concepts to make the classroom and school more efficient and effective.

According to Johnson (Trianto, 2010) to know the quality of learning models should be seen from two aspects, namely processes and products. Aspects of the process refers to whether learning is able to create a fun learning situation (joyfull learning) and encourage students to actively learn and think creatively. Product aspect refers to whether the learning is able to achieve the goal, which is to improve students' ability in accordance with the standard of ability or competence specified.

\section{CONCLUSIONS AND SUGGESTIONS} Conclusion

Based on the stages that have been done, the conclusions generated as a result of this study are: (1) description of the application of SQ3R method in the social science study of SMA XI class; (2) the quality of social sciences learning has increased significantly; and (3) IPS learning outcomes in high school students of class XI increased.

\section{Suggestion}

We recommend that in the implementation of learning with a broad and complex material, recommended some of the following suggestions: (1) present the learning materials, should pay attention to the method of learning in accordance with the ability of understanding of learners; (2) teachers in conveying learning, need to apply some new techniques or methods in learning / reading effectively. It is important to avoid student learning saturation; and (3) SQ3R learning model, can be used as reference material or comparison in implementing learning practices on the eyes of other relevant subject matter.

\section{REFERENCES}

[1] Edwards, W. 2011. Quality Learning Australia. Retrieved December 9, 2016, from http://www.qla.com.au/pages/AboutQL.html.

[2] Joyce, B., \& Weil, M. 1992. Models of Teaching. Boston: Allyn and Bacon.

[3] Kiranawati. 2008. Teknik Membaca Cepat. Jakarta: Pustaka.

[4] Louis, K. P. 1994. The Continuing Education Guide: The Ceu and Other Professional Development Criteria. Dubuque, Iowa: Hunt Publishing, Co.

[5] Miarso, Y. 2004. Menyemai Benih Teknologi Pendidikan. Jakarta: Kencana Prenada Media Group.

[6] Sagala, S. 2004. Manajemen Berbasis Sekolah \& Masyarakat. Bandung: Alfabeta.

[7] Trianto. 2007. Model Pembelajaran Terpadu dalam Teori dan Praktik. Jakarta: Prestasi Pustaka Publisher. 